\title{
A HISTORICIDADE DO PERCURSO DO GT TRABALHO E EDUCAÇÃO: UMA ANÁLISE PARA DEBATE
}

\author{
WORK AND EDUCATION GT'S PATH HISTORICITY: AN ANALYSIS FOR DEBATE
}

Eunice Trein ${ }^{1}$

Maria Ciavatta $^{2}$

Resumo Neste trabalho, retomamos os aspectos principais de um trabalho anterior que teve o objetivo de dar prosseguimento ao balanço da produção científica do GT Trabalho e Educação, a partir dos trabalhos selecionados e discutidos pelo grupo nas Reuniões Anuais da Anped (1996 a 2001), retomando a pauta de temáticas apresentadas em balanços similares, analisando a produção de 2002 a 2007. Do ponto de vista teórico-metodológico, o GT orientase pelo materialismo histórico, contempla também a discussão de outras linhas teóricas e tem como compromisso a transformação das formas de exploração e amesquinhamento do ser humano. Do ponto de vista dos conteúdos, os temas recorrentes mais presentes são os seguintes: trabalho e educação teoria e história; trabalho e educação básica; trabalho e educação nos movimentos sociais; educação do trabalhador nas relações sociais de produção; e profissionalização e trabalho que se constituem no tema principal do período mais recente que analisamos neste texto.

Palavras-chave trabalho e educação; teoria e história; profissionalização; educação dos trabalhadores; educação básica.
Abstract In this paper, we resume the main aspects of a previous paper that aimed at continuing the report of Work and Education GT's scientific production, from the papers selected and discussed by the group at Anped's Annual Meetings (1996 to 2001), resuming the agenda of issues presented in similar reports, analyzing the production from 2002 to 2007. From the theoretical and methodological point of view, GT is guided by the historic materialism, also contemplating the discussion of other theoretical lines and it is committed to the transformation of exploration and belittling forms of the human being. From the point of view of the contents, the most present recurrent issues are as follows: work and education - theory and history; work and basic education; work and education within social movements; worker education in the social relations of production; and enhancement of skills and work which are constituted within the main issue of the most recent period analyzed in this text.

Keywords work and education; theory and history; enhancement of skills; workers' education; basic education. 
Como refletimos anteriormente, ${ }^{3}$ a área de pesquisa trabalho e educação é profundamente vincada pelos problemas socioeconômicos a que chegamos na atual etapa do capitalismo, de modo especial, do capitalismo dependente a que se submetem os países em desenvolvimento, como o Brasil (Ciavatta e Trein, 2006). A carência de moradia, saneamento e alimentação adequados, o atendimento à saúde e à educação, assim como a ideologia do consumo supérfluo que pauta as condições de vida de milhões de pessoas no mundo atual, obrigam os pesquisadores da área à análise da relação capital e trabalho e do capitalismo, proporcionada pela crítica à economia política e aos conceitos de trabalho, mercadoria e alienação.

Mas são escassos os estudos que articulam os conceitos básicos de trabalho necessário e trabalho alienado com a pesquisa documental e a reconstrução histórica dos fenômenos do mundo do trabalho e da educação. A produção historiográfica é incipiente. Em parte, talvez, devido às urgências das questões do presente, que envolvem o capital e a sobre-exploração do trabalho em sociedades desiguais como a brasileira. Em parte, talvez, à carência de recursos e de tempo para a pesquisa em arquivos. Ou, ainda, porque, à exceção de poucos, raros são os historiadores que se dedicam ao estudo da educação ${ }^{4}$ e, consequentemente, estudam o trabalho em suas diversas formas e temporalidades, mas não a relação entre o mundo do trabalho e a educação ou a escola. Não significa que, com o método da economia política, não alcancem alguma historicidade. Mas não há debates sobre a natureza da história como acontecimento e relato. Predominam as análises com base nos conceitos mais gerais do materialismo histórico. A palavra história, que vem do grego istoria, quer dizer 'indagação' e 'relato' (Raymond Williams, 2007) e tem, hoje, significados de grande complexidade do ponto de vista das concepções que abriga e da complexidade dos fatos que relata.

Se buscamos conhecer a abordagem histórica da relação trabalho e educação, chegamos à discussão da historiografia, um tema não apenas da moda entre os historiadores de ofício mas, principalmente, de amadurecimento do campo científico que pensa sobre seu próprio fazer. Se na área trabalho e educação são escassos os temas desenvolvidos a partir do conceito de história, tal como expressa Marx (1979), em A ideologia alemã, a história como produção social da existência dos seres humanos em sociedade, qual o sentido de sua historicidade?

Temos por hipótese que falta pesquisa empírica e documental pesquisa com documentos de época (fontes primárias). Mas levar adiante essa discussão seria avançar no estudo da historiografia, de como se escreve a história em trabalho e educação. E não é esse o objetivo deste texto. Apenas queremos recuperar a historicidade 5 do percurso teórico-empírico do GT Trabalho e Educação da Associação Nacional de Pós-Graduação e Pesquisa em Educação (Anped), a partir de sua documentação mais expressiva, os 
trabalhos selecionados e apresentados durante a Reunião Anual, na sua continuidade, de 2002 a 2007. Damos, assim, prosseguimento ao trabalho anterior publicado na Revista Educação Brasileira, da Anped (Trein e Ciavatta, 2003). O trabalho que realizamos contemplou os seguintes aspectos:

- recuperar os trabalhos sobre o histórico do GT e sobre o 'estado do conhecimento' do tema trabalho e educação disponíveis: Kuenzer, 1987, 1988; Picanço, 1995; Trein, 1996a, 1996b, 1998; e Shiroma e Campos, 1997;6

- proceder à leitura dos resumos dos trabalhos apresentados e discutidos no GT de 1996 a 2001;

- fazer o levantamento das questões conceituais, teórico-metodológicas e empíricas dos trabalhos apresentados;

- finalmente, fazer a leitura e análise de vários textos completos que desenvolveram as temáticas mais recorrentes em cada reunião anual do GT.

Neste texto, 7 damos continuidade à análise iniciada. No período de 2002 a 2007, é a questão da educação profissional que emerge com destaque, em face das reformas que sucederam a Lei de Diretrizes e Bases (LDB, lei n. ${ }^{\circ}$ 9.394/96). Primeiramente, durante o governo Fernando Henrique Cardoso, o decreto n. ${ }^{\circ}$ 2.208/97, com a implantação na rede federal dos Centros Federais de Educação Tecnológica (Cefets) e das escolas técnicas e agrotécnicas, apoiada com recursos do Programa de Expansão da Educação Profissional (Proep) - reforma da educação profissional, portaria MEC n. ${ }^{\circ}$ 1.005/97 - , assim como do Plano Nacional de Qualificação do Trabalhador (Planfor), com base nos recursos do Fundo de Amparo ao Trabalhador (FAT). Em um segundo momento, já no governo Lula, o decreto n. ${ }^{\circ}$ 5.154/04 que revogou o decreto $n .^{\circ} 2008$ e restaurou a alternativa da formação integrada em todo o sistema de educação profissional, em meio a grande polêmica. Em paralelo, na ausência de uma política nacional de educação básica (incluindo o Ensino Médio) para toda a população, criou programas de governo para diferentes segmentos da juventude, como o Programa de Integração da Educação Profissional ao Ensino Médio na Modalidade Jovens e Adultos (Proeja - decreto n. ${ }^{\circ}$ 5478/2005), o Programa Nacional de Inclusão de Jovens (Projovem - medida provisória n. ${ }^{\circ}$ 238/2005) e o Projeto Escola de Fábrica (medida provisória . $^{\circ} 251 / 2005$ ).

Por ser uma área de estudos ligada às relações capital e trabalho, as transformações socioeconômicas e políticas precisam ser reconhecidas e estudadas. Trata-se de compreender o contexto político-econômico mais amplo, o campo empírico onde as pesquisas se realizam, as categorias e os conceitos privilegiados pelos diversos autores em seus trabalhos e o sentido político das análises desenvolvidas. 


\section{O caminho teórico-metodológico percorrido pelo GT Trabalho e Educação}

O que distingue, basicamente, um grupo de trabalho é a atividade coletiva em torno de certos objetivos comuns. O GT Trabalho e Educação da Anped caracteriza-se como um grupo de pesquisadores desta área de estudos, tendo em vista a natureza da entidade a que pertence. Não seria um grupo de pesquisa em senso estrito, porque seus participantes não pesquisam, necessariamente, juntos. O GT Trabalho e Educação funciona como fórum de debates em torno de uma temática comum: as relações que se estabelecem entre o mundo do trabalho e a educação, nelas cabendo formação profissional, formação sindical, reestruturação produtiva, organização e gestão do trabalho, trabalho e escolaridade, subjetividade e trabalho etc.

Do tratamento desses temas participam pesquisadores juniores e seniores de muitas instituições, trazendo à discussão suas pesquisas, dissertações de mestrado e teses de doutorado. Pode-se inferir daí a grande heterogeneidade de ideias e de procedimentos que permeiam os trabalhos que são selecionados pelo Comitê Científico, para apresentação pelo mérito, segundo os critérios de "relevância e pertinência do trabalho para a discussão em sua área de pesquisa", "coerência e consistência argumentativa na formulação do problema, no desenvolvimento do trabalho" e "interlocução com a produção do conhecimento na área" (Anped, 2002, p. 8).

No entanto, há uma questão recorrente: a preocupação teórico-metodológica, que não é única, porque o GT preserva o espaço plural de discussão, mas, para a compreensão da área e de seus problemas em profundidade, é fundamental a visão da realidade e da história como produção social da existência humana. Em documento elaborado após um encontro de pesquisadores do GT, patrocinado pelo Conselho Nacional de Desenvolvimento Científico e Tecnológico (CNPq) em 1986, Kuenzer (1987, p. 93) registra

a necessidade de desenvolver o corpo teórico da área, através de um concentrado esforço de reflexão sobre os fundamentos teórico-metodológicos da relação entre trabalho e educação, atentando para os perigos da manipulação de conceitos gerais como se fossem uma substantividade própria, independentemente de tempo e lugar.

\footnotetext{
Afirmava-se que

a única alternativa que se coloca como válida para superar um tratamento apenas ideológico das questões é compreendê-las em sua situação histórica concreta; neste sentido, a constituição de um corpo teórico para o exame da relação trabalho e educação implica a reconstrução histórica como aspecto fundamental dessa reflexão (Kuenzer, 1987, p. 93).
} 
Essa base teórica pautada no materialismo histórico segundo Marx traz consigo outro traço distintivo do GT: a visão política centrada no compromisso com a transformação das formas de exploração e amesquinhamento do ser humano, geradas pela produção e pela sociabilidade do capital. Tem prevalecido, contudo, o diálogo e o confronto com autores que questionam o marxismo ou que trazem contribuições analíticas orientadas para temas emergentes no contexto das transformações do último século, tais como a sociedade de consumo, a comunicação, a subjetividade, a presença da imagem e o ideário pós-moderno. 8

A relação entre o trabalho e a educação é um tema tratado desde o século passado tanto pela economia política burguesa quanto pela marxista. No Brasil, até os anos 1970, predominavam os estudos ligados à economia da educação e à formação profissional e técnica. Com a redemocratização do país em curso nos anos 1980, a tentativa de construção de novo projeto hegemônico e a afirmação de alguns cursos de pós-graduação em educação rumo a uma visão crítica e dialética, o tema trabalho e educação aparece vinculado à superação do autoritarismo e comprometido com as lutas dos trabalhadores por maior participação política e econômica.

A partir de então, as pesquisas passaram a buscar "a compreensão dos processos pedagógicos escolares e não-escolares a partir do mundo do trabalho, tomando-se o método da economia política como diretriz para a construção do conhecimento" (Kuenzer, 1998, p. 55). Tentava-se superar os limites herdados do enfoque restrito à formação profissional para o desenvolvimento econômico, a teoria do capital humano, o tecnicismo e as teorias reprodutivistas (Franco, 1990). Os temas subjacentes às discussões sobre a profissionalização, a preparação para o trabalho e a educação do trabalhador eram o trabalho como princípio educativo e a politecnia.

Nos anos 1990, Shiroma e Campos (1997), fazendo um balanço das pesquisas em educação sobre qualificação e reestruturação produtiva, registraram a presença de profissionais de áreas afins nos eventos de educação: da sociologia do trabalho, da engenharia de produção e da administração. Os estudos vão receber influência dessas áreas quanto ao quadro de referências conceituais, às abordagens, à apropriação de conceitos e ao delineamento das pesquisas.

Do ponto de vista teórico-metodológico, no presente artigo, valemo-nos de estudos similares denominados 'estados da arte' ou 'estados do conhecimento'. Azevedo e Aguiar (2001) fizeram um estudo da produção do conhecimento sobre política educacional no Brasil a partir da produção apresentada no GT Estado e Política Educacional, no período de 1993 a 2000. Com base em Bourdieu, trazem, como questões preliminares, os processos de reconhecimento e legitimidade conferidos àqueles que participam de um determinado campo científico. Para essas autoras, a estrutura que se cria em um campo depende 
do tipo de luta científico-política pela legitimidade do saber, o que também é influenciado por fatores externos ao campo.

Neste contexto, em todos os campos são encontrados os dominantes, cujas posições advêm do reconhecimento do montante do capital científico de que são detentores, e os dominados, ou novatos, que necessitam ter reconhecida a importância de seu capital, de suas potencialidades, bem como de sua posição atual e potencial no campo. Entretanto, é o resultado do jogo de forças nele presentes que vai permitir, ou não, o avanço significativo da produção do conhecimento de que o campo se ocupa (Bourdieu apud Azevedo e Aguiar, 2001, p. 50).

No caso do GT Trabalho e Educação, o reconhecimento do campo se fez com clara explicitação da busca de afirmação política dos setores progressistas da sociedade civil em processo de democratização nos anos 1980 e de crítica às políticas neoliberais nos anos 1990. O movimento de legitimação do materialismo histórico como referencial analítico fundamental do campo se fez, de modo particular, no primeiro momento, pelas lideranças incisivas e permanentes de Miguel Arroyo e Gaudêncio Frigotto, desde a criação do GT até meados dos anos 1990. Complementarmente, atuaram Acácia Kuenzer, na vinculação do campo com o Ensino Médio e na 'pedagogia da fábrica'; Lucília Machado, na discussão do ensino técnico e da politecnia; Paolo Nosella, nos estudos gramscianos; Maria Ciavatta Franco, nos estudos históricos com documentação de época; Ozir Tesser, no referencial lukacsiano; e Celso Ferretti, nos estudos sobre tecnologia e reestruturação produtiva.

Em um segundo momento da história do GT, emerge de modo significativo o questionamento às análises marxianas, através de Werner Markert e seus estudos sobre profissionalização e competências, tendo por base o referencial da Escola de Frankfurt. Nesse momento, também se fazem presentes, com Paulo Tumolo, os estudos sobre sindicalismo, além de alguns trabalhos polêmicos com base em autores ditos pós-modernos.

Com o crescimento da afluência às reuniões anuais da Anped, no início dos anos 1990, cria-se o Comitê Científico para a avaliação crítica dos trabalhos (o que, antes, era feito pelos coordenadores dos GTs). Introduzem-se as mesas-redondas e os trabalhos encomendados. No GT Trabalho e Educação, abrem-se novos espaços de participação, com uma seleção de temas a cargo dos participantes mais expressivos do GT e de convidados, ao lado da apresentação de trabalhos, comunicações ou pôsteres por novos participantes vindos dos mestrados e doutorados em expansão no país.

Do ponto de vista do 'estado do conhecimento' que nos propomos a fazer, cabem alguns comentários. Ferreira (2002) analisa estes tipos de estudos e seus desafios ao mapear uma certa produção acadêmica em diferentes campos do conhecimento, tempo e lugar, a partir de diversas formas de apresentação 
(teses, dissertações, artigos em periódicos, comunicações em congressos e seminários). Os catálogos (impressos ou em CD-ROM) vão permitir a socialização de uma produção científica crescente nas universidades, proporcionam os primeiros contatos entre pesquisadores e o rastreamento do que já foi estudado, caracterizam seu conteúdo e divulgam os dados bibliográficos dos autores. Os resumos são elaborados para elucidar o objetivo principal da investigação, a metodologia e os procedimentos utilizados, os sujeitos da pesquisa, os resultados e as conclusões.

A pergunta básica da autora é se é possível interrogar a história da produção acadêmica a partir apenas da leitura de dados bibliográficos e resumos dos trabalhos. É possível inventariar a produção, suas tendências, escolhas metodológicas e teóricas por um processo de aproximação ou de distanciamento entre os trabalhos expressos nos resumos, sem ter o contato com o todo? Há sempre o risco de se classificar ou agrupar erradamente os trabalhos. ${ }^{9}$

Várias questões se colocam: os resumos não são homogêneos na sua estrutura e na ênfase aos diferentes aspectos resumidos; de uma mesma obra, pode ter sido feito mais de um resumo, com ênfases diversas, apresentando diferentes pistas ou indícios da pesquisa; a história da produção acadêmica analisada será sempre "umas das possíveis histórias" (Ferreira, 2002, p. 269, grifo da autora). Há um certo relativismo, não claramente explicitado no trabalho, trazido pela polifonia dos resumos e das leituras possíveis dos mesmos, que seria 'resolvido' através da noção de rede.

Mas é válido o alerta sobre os riscos de se tomar a parte pelo todo, ao analisar apenas os resumos com o objetivo de construir a história da produção acadêmica de determinado grupo, em certo período. Embora, conforme a autora, "é possível ler em cada resumo e no conjunto deles outros enunciados, outros resumos, outras vozes, e perceber a presença de certos aspectos significativos do debate sobre determinada área do conhecimento" (Ferreira, 2002, p. 270), desde que não se reduza a pesquisa ao resumo e não se veja entre os resumos uma relação de contiguidade, já que em cada resumo haveria uma relação de continuidade e de ruptura com o trabalho que lhe dá origem.

O GT Trabalho e Educação desenvolveu-se com características muito próprias. Num debate ocorrido durante a $9^{a}$ Reunião Anual, Miguel Arroyo assim se expressou sobre a orientação assumida pelo GT: “Tentamos dar-lhes uma conotação de debate, de verdadeiro intercâmbio, e não só de apresentação. Debatemos principalmente as demandas que estão surgindo, para as quais precisamos de respostas novas, para o que ainda não há muitos espaços" (Trein e Picanço, 1995, p. 87).

Inicialmente, o GT denominou-se Educação e Trabalho, mas a concepção de trabalho como práxis humana, material e não-material, que constitui o trabalho como princípio educativo - e que, portanto, não se encerra 
na produção de mercadorias -, exige que a educação seja compreendida em suas múltiplas determinações, conforme o estágio do desenvolvimento das forças produtivas e das relações de produção. Dentro de uma visão dialética da história, no quadro dos estudos e publicações sobre Marx e Gramsci, formouse a ideia de que não se pode compreender a escola dissociada da sociedade a que ela pertence. Nesse sentido, a escola e a educação não devem ser estudadas como unidades autônomas, mas dentro das relações sociais de que fazem parte. Essas reflexões determinaram a mudança do nome do GT para Trabalho e Educação (Kuenzer, 1987).10

\section{A produção científica do GT Trabalho e Educação (1996-2007)11}

Retomando a pauta elaborada no encontro coordenado por Kuenzer em 1987, Trein (1996a), no balanço das temáticas propostas em 1986 e de seus desdobramentos ao longo de dez anos, destacou os seguintes temas e subtemas:

- Educação e trabalho - teoria e história: o trabalho como princípio educativo; a evolução histórica do conceito de trabalho; a relação trabalho e educação e sua reconstrução histórica.

- Trabalho e educação básica: o trabalho e a continuidade/descontinuidade da escolarização do trabalhador; o mundo do trabalho; a escola e a formação científico-tecnológica do trabalhador.

- Trabalho e educação nos movimentos sociais: a construção de identidades de diferentes categorias de trabalhadores; demandas de conhecimentos científico-tecnológicos dos movimentos sociais a partir da produção; a ação pedagógica nas formas cooperativistas de organização dos trabalhadores.

- Educação do trabalhador nas relações sociais de produção: reestruturação produtiva; apropriação do conhecimento nos processos produtivos; a organização da produção e suas propostas pedagógicas; a escola, o trabalho, a sociedade e a construção da hegemonia.

- Profissionalização e trabalho: a análise histórica das políticas de profissionalização definidas pelo Estado; trabalho, conhecimento e cidadania para a emancipação do trabalhador.

No presente artigo, primeiro recuperamos algumas questões das temáticas mais recorrentes nas reuniões anuais do GT, de 1996 a 2001, classificadas de acordo com as categorias anteriores, onde buscamos identificar quais desses temas permanecem e quais as temáticas emergentes. Em linhas gerais, observamos dois grandes eixos temáticos - a reestruturação produtiva e a nova organização do trabalho - e suas consequências para a formação profissional, tema que ganha destaque no momento subsequente, objeto de nossa análise neste texto. 
Em termos de maior número de trabalhos, estavam os estudos sobre a relação trabalho e educação e seus pressupostos teórico-metodológicos. Em menor número, os textos sobre o trabalho e a educação básica e os referentes a trabalho e educação e os movimentos sociais. Aparecem também outras temáticas às quais poucos têm se dedicado no GT, tais como: trabalho infantil, trabalho, gênero e etnia, tele-educação.

Do ponto de vista do campo empírico de pesquisa, predominam os trabalhos que se ocupam da revisão analítica da literatura produzida sobre o tema e subtemas. Mas um número considerável deles tem como campo empírico empresas, sindicatos e escolas, a partir de observação, entrevistas com gerentes e trabalhadores e análise de documentação.

\section{Trabalho e educação - teoria e história}

Até 1996, a análise efetuada sobre esta temática indicava que o trabalho como princípio educativo era recorrente em nossas discussões, tendo como matriz principal o materialismo histórico (Marx, Lukács e Gramsci). Mas já incorporava os teóricos da Escola de Frankfurt, onde se enfatiza a formação do sujeito, embora ainda no âmbito do projeto da modernidade (Trein, 1996a).

Essa questão de fundo, a matriz marxista que orientou a produção básica do GT desde seu início, foi pesquisada por Bomfim (2006, p. 15) que destacou a abertura para a discussão de trabalhos com outros referenciais e os desafios ao GT trazidos por outras “teorias, e ideários 'adversários', vindos dos pós-modernismos, do neoliberalismo, dos críticos à centralidade do trabalho etc.". 12

Continuam recorrentes no GT o conceito de trabalho, a relação trabalho e educação e sua reconstrução histórica, que permanecem como temas de interesse do grupo, mas com tratamento diferenciado. Embora o enfoque marxiano seja necessariamente do objeto compreendido na sua historicidade, são raros os trabalhos de resgate histórico da relação trabalho e educação com fontes documentais de época que não sejam do presente (Nosella e Buffa, 1997; Ciavatta Franco, 1998b; Moraes e Ciavatta Franco, 1999). O estudo dos fenômenos é feito, via de regra, a partir de problemas atuais ou do passado recente.

Observamos um retorno aos clássicos, notadamente Marx e Lukács, realizando uma releitura crítica dos mesmos diante dos problemas postos pela globalização ou pela mundialização do capital. Tumolo (1996) faz uma análise da temática trabalho e educação propondo que se discuta o fenômeno educacional à luz do novo padrão de 'acumulação flexível de capital'. O autor conclui que, quaisquer que sejam os processos de trabalho, modelos ou trajetórias, é necessário “compreendê-los como processos subordinados ao 
processo de valorização do capital, ou seja, ao processo de produção capitalista", em um trabalho analítico que vai do "concreto aparente" ao "concreto pensado" e, assim, buscar desvendar suas múltiplas determinações e contradições (Tumolo, 1996, p. 13-15). Mais adiante, Tumolo (2000) retoma a questão conceitual tratando "da subsunção formal do trabalho à subsunção real da vida social ao capital".

Santos (1996) parte do conceito marxiano de trabalho concreto e trabalho abstrato e, segundo uma releitura de autores franceses, principalmente Ives Schwartz, discute a relação entre concepção e execução, entre trabalho prescrito e trabalho real, como espaço de saber dos trabalhadores que possibilita o desenvolvimento de um projeto tecnológico.

Analisando outro ângulo da questão temática, Leher (1996, p. 11) critica a noção de tempo linear, hegemonizado pelo modo de produção capitalista e implícito nas políticas do Banco Mundial, que concebe a relação entre trabalho e educação como o "principal meio capaz de conduzir os países, regiões e pessoas a se ajustarem ao tempo hegemônico onde a educação confundir-se-ia com as categorias do tempo, desenvolvimento e crescimento".

A questão teórica é preocupação também do ponto de vista do indivíduo e de sua individualidade na sociedade capitalista. Palangana (1998) parte de pensadores clássicos e contemporâneos para analisar as condições sóciohistóricas nas quais emerge o indivíduo burguês, a consciência de si, a submissão e o controle da individualidade.

Frigotto (1998) apresenta uma reflexão sobre a questão teórica, assinalando: os desafios teórico-metodológicos da relação trabalho e educação, no contexto da crise dos paradigmas das ciências sociais, e a forma como os estudiosos da área constroem suas análises sobre o papel da educação e da formação técnico-profissional na produção social da existência. Para ele, o grande desafio colocado para o GT é "apreender as mediações no plano econômicosocial, cultural, simbólico e educativo" (Frigotto, 1998, p. 50) que articulam as lutas das classes trabalhadoras, as formas de organização do trabalho e os processos educativos que emergem da organização dos excluídos, a exemplo do Movimento dos Trabalhadores Rurais Sem Terra (MST) e dos processos que vêm sendo denominados como 'economia popular'.

No mesmo ano, Kuenzer (1998) dedica-se ao exame das relações entre trabalho e educação na constituição do GT. Recupera duas de suas preocupações iniciais: compreender a pedagogia capitalista e identificar os espaços de contradição que tornam possível a construção histórica de uma nova pedagogia, "inscrevendo-se a produção do GT no campo do materialismo histórico, que toma a dialética como lógica e teoria do conhecimento" (Kuenzer, 1998, p. 55).

A centralidade do trabalho e a centralidade da educação são discutidas por Castro (1998), que questiona as pseudoevidências do senso comum pós- 
moderno sobre a era pós-trabalho, centrada no conhecimento e na educação. O pensamento empresarial estaria exigindo a mercantilização ampla e irrestrita do ensino através da atuação mais incisiva do empresariado. A centralidade da educação modernizada assenta-se no falso pressuposto da correlação direta entre educação e emprego, na ideologia da 'empregabilidade'. Critica ainda a "visão neo-racionalista (Offe, Habermas, Gorz, Kurz) [em que] o trabalho assalariado teria deixado de ser o fundamento estruturante da sociedade moderna" (Castro, 1998, p. 13).

Markert (2000, p. 146) pergunta se "neste novo modelo de competências podemos encontrar somente uma 'mistificação' da antiga discussão sobre as mudanças da qualificação no capitalismo, ou trata-se realmente de um conceito pedagógico universal que reflete o novo patamar dos conceitos de produção". Partindo do referencial habermasiano, o autor faz uma releitura de Marx, segundo o qual "o conjunto das relações sociais" é entendido "na dialética entre atividade produtiva (trabalho) e relação humana (comunicação)" (Markert, 2000, p. 37). Embora não sinalizada pelo autor, a questão polêmica que emerge deste tipo de análise é a primazia da comunicação nas relações capital e trabalho, em detrimento da estrutura de classes. Em 2001, Markert volta ao tema tentando apresentar 'uma concepção emancipatória da competência'.

Na mesma linha teórica, Nogueira (2001, p. 11) filia-se aos pensadores que buscam "descentrar o trabalho como determinante social" e critica Marx e o marxismo, focalizando o diálogo de Habermas com Lukács, na busca de "uma teoria que aponte para a emancipação do homem". O ano de 2001 caracteriza-se pela preocupação e pela polêmica em torno de questões teóricas, particularmente o marxismo e a teoria de Harbermas. Ferreira (2001) trata da crise dos referenciais e os pesquisadores em trabalho e educação.

Em trabalho encomendado pelo GT para a $23^{a}$ reunião, realizada em 2000, Frigotto (2001, p. 21) faz um balanço da "nova e da velha faces da crise do capital e o labirinto dos referenciais teóricos". Tendem a prevalecer as teorias conservadoras que naturalizam o capitalismo como única realidade possível. Sua crítica fundamental é que tais posturas não distinguem a permanência do modo de produção capitalista que continua vigente e as novas formas com que se apresenta.

Entre 2002 e 2007, mantêm-se no GT as referências teóricas com base na crítica à economia política, à análise da mercadoria e da alienação e suas relações com a educação e, como já foi apontado em relação ao período anteriormente analisado, as pesquisas referem-se, de preferência, aos desafios postos pelos problemas atuais ou do passado recente.

A retomada do conceito de classe se faz à luz do capitalismo atual (Markert, 2002d), onde o autor se propõe a considerar a consciência de classe segundo a análise marxista. Mas, para a reconstrução do conceito de classe social, é importante um processo de conscientização política entre a "intermediação 
do subjetivamente interpretado com o geral coletivo" dos trabalhadores e a relação 'abstrata' entre capital e trabalho.

Também Trópia (2007) debate no âmbito da teoria marxista a inserção de classe dos trabalhadores em educação, tema que, por seus conflitos e contradições merece maiores estudos. A questão do método retorna nos estudos de Araújo (2002) discutindo a atualidade de Marx e Lukács para desvendarmos como se dá a apreensão do real. A dimensão ontológica da sociabilidade humana é tratada em duas vertentes recorrentes no GT: na perspectiva lukacsiana, onde o trabalho é o conceito central (Tassigny, 2005), e na perspectiva habermasiana, onde a articulação linguagem e trabalho constitui o especificamente humano (Bomfim, 2002).

A discussão sobre a escola unitária e o ensino politécnico retorna em diversos textos ao longo dos anos, mas nos parece mais como uma denúncia da impossibilidade de sua realização sob o modo de produção capitalista do que numa tentativa de retomar de forma radical o conceito como estratégia política propositiva. O que implicaria pesquisas que buscassem apreender, na luta concreta dos trabalhadores, os processos educativos que apontem para a construção de uma outra sociedade e de outros processos educativos que não sejam apenas a educação para o mercado.

\section{Trabalho e educação básica}

No documento produzido a partir do seminário ocorrido em 1986 (Kuenzer, 1987), os pesquisadores da área apontavam a necessidade de se discutir o tema 'trabalho e educação básica' sob duas dimensões principais:

a que assume esta relação a partir do trabalhador, no âmbito do trabalho coletivo, como um 'aluno' que já ocupa um posto de trabalho e (...) a que assume esta relação a partir da 'agência formadora', subentendendo-se aí o caráter mediador do Estado, que indicará a existência de distintas formas educativas para distintos grupos de trabalhadores, o que revestirá a educação básica de distintas concepções (Kuenzer, 1987, p. 93).

Hoje, tal como tem sido tratado, o tema ampliou-se e apresenta uma complexidade maior na medida em que as investigações empíricas recaem sobre o enfoque dado pelos empresários, o enfoque sindical e também sobre o imbricamento entre o público e o privado.

No trabalho de Rummert (1998), são cotejados os diferentes discursos que explicitam as concepções de educação básica de qualidade formuladas pelas entidades representativas dos empresários e entidades representativas dos trabalhadores. Aponta convergências entre trabalhadores e empresários 
quanto a uma visão negativa em relação à qualidade do ensino básico e ao papel da educação para que ocorram transformações no sistema produtivo. Para a autora, esse pensamento convergente nega o valor pedagógico das lutas travadas pelos trabalhadores ao longo da história, atribuindo à educação formal orientada para o mercado o poder de grande panaceia para superar as dificuldades que afetam tanto o capital quanto o trabalho.

A mesma temática que pudemos identificar diz respeito a um pseudoconsenso na sociedade que coloca a educação básica para os trabalhadores na ordem do dia. Cêa (1999) busca desvelar os elementos contraditórios desse consenso sobre o tema, apontando que, por trás dessa investida ideológica da classe dominante, o que aparece é a ênfase numa educação básica para os trabalhadores que viabilize a construção de um país competitivo num cenário de economia globalizada.

Nesse e em outros trabalhos apresentados no GT, desvela-se o caráter ideológico dos pressupostos que enfatizam a relevância da educação básica dos trabalhadores. São elididos os condicionantes econômicos e políticos de uma materialidade histórica que não estende ao conjunto da sociedade os avanços proporcionados pelo desenvolvimento das forças produtivas.

Abordagem relevante da relação trabalho e educação básica é a que diz respeito à cidadania. Em Andrade (1998), encontramos o tema tratado à luz das demandas de uma sociedade 'conformada' às mudanças das transformações produtivas. Nela, a tarefa da educação é a formação de uma força de trabalho adequada aos requisitos técnico-comportamentais desse novo momento da reestruturação produtiva, enquanto a burguesia industrial critica a questão da cultura própria da formação social brasileira como um dos entraves ao desenvolvimento do país e propõe uma educação imbuída dos valores do industrialismo e da qualidade.

O tema da cidadania aparece também em estudo de caráter teórico-conceitual quando o enfoque dado é de contraposição ao ideário liberal. Em Portela (2000), através de um estudo de reconstrução histórica do conceito, são enfocadas as ações governamentais e questionadas as possíveis contribuições educacionais para a construção de uma cidadania para a emancipação humana.

Outra face da complexa relação trabalho e educação básica dos trabalhadores diz respeito à influência da teoria do capital humano, revisitada no discurso empresarial. No estudo empírico realizado por Silva (2002), são analisadas as ações decorrentes da lógica empresarial veiculadas nos conteúdos não manifestos no currículo escolar, mas que permeiam o espaço pedagógico.

Nos últimos anos que compreendem o período de 2002 a 2007, se, de um lado, consolidou-se a compreensão da educação básica como a escolarização fundamental e média, de outro lado houve uma dispersão de formas de concretizar este objetivo através dos programas de governo, tais como o Proeja, o Projovem, o Escola de Fábrica e as iniciativas de organizações não- 
governamentais e dos empresários, como a alfabetização nos canteiros de obras e inúmeras outras ações ditas de 'responsabilidade social' das empresas.

Os trabalhos apresentados no GT expressam alguns desdobramentos que a temática sofreu, principalmente pelo aparente consenso na sociedade sobre a necessidade de elevação da escolaridade da classe trabalhadora, não mais com ênfase na cidadania, como mostram os trabalhos apresentados nos anos anteriores. Hoje, mais focados na contribuição que a força de trabalho mais escolarizada pode dar a uma economia em desenvolvimento, globalizada e extremamente competitiva. Convergem os discursos dos empresários e do próprio governo nesse sentido. No entanto, as pesquisas evidenciam que os trabalhadores num primeiro momento reproduzem o discurso hegemônico sobre a importância da educação para a inclusão no mercado de trabalho. Mas percebem, e os dados dos trabalhos apontam, que apenas a escolarização, desvinculada de outras políticas sociais de emprego e renda, de proteção ao trabalho, não os livrará do desemprego, dos trabalhos precarizados, das incertezas quanto ao futuro.

Santos (2005), em sua pesquisa sobre o papel da família e da escola na formação dos trabalhadores, alerta para o fato de que eles reconhecem essa influência, principalmente nos aspectos ético-morais que se expressam através de valores, atitudes e competências para o trabalho flexível. Quer nos parecer que isso ocorre na medida em que as empresas se inserem nos ambientes comunitários, chegando às escolas como parceiras através do trabalho voluntário e dos recursos financeiros.

Também Trojan (2005) aponta para a estetização pós-moderna presente na relação entre trabalho e educação, onde a estética de sensibilidade, definida como princípio curricular, ao invés de valorizar o conhecimento privilegia um conjunto de saberes onde os aspectos comportamentais e afetivos são priorizados.

Correlato a esse tema - a articulação entre trabalho e educação básica verificamos uma crescente preocupação por parte dos pesquisadores do GT com a formação docente. Na medida em que empresários e o governo convergem para a defesa de uma maior escolaridade para os trabalhadores e confrontados com os baixos níveis de desempenho dos estudantes verificados pelos sucessivos processos de avaliação implantados no país, a atenção volta-se para os docentes e sua formação.

Sem considerar os condicionantes sócio-históricos que ocasionam a má qualidade da educação oferecida à classe trabalhadora, inúmeras propostas de formação continuada e de elevação de escolaridade dos docentes são elaboradas. Nessas, à semelhança do que ocorre na formação profissional técnica, a teoria das competências orienta as reformas curriculares e os processos avaliativos de desempenho profissional. Soares (2006) destaca três eixos presentes nas políticas e nas práticas docentes: a diminuição da 
relevância do conhecimento frente a uma excessiva valorização da prática e adesão à pedagogia das competências na formação dos trabalhadores incluindo os docentes.

\section{Trabalho e educação nos movimentos sociais}

É preciso investigar a inserção dos trabalhadores no processo de produção, organização e gestão das condições pedagógicas específicas dos movimentos sociais para conhecer as dimensões educativas presentes nos movimentos dos trabalhadores e sistematizar as exigências educacionais ao seu pleno desenvolvimento.

Osowski e Martini (1996) pesquisaram os trabalhadores infanto-juvenis que frequentam escolas de Primeiro Grau. Discutem as representações sociais sobre o trabalho infantil, as várias apreensões que a sociedade tem do fenômeno, como as crianças vivenciam esse aprendizado e as possíveis relações que a escola estabelece entre o currículo oficial e o 'currículo oculto', presente na cultura dos jovens trabalhadores e seus familiares.

Resende (1999) compreende a construção da subjetividade a partir do mundo do trabalho, das condições materiais da produção da existência. Ressalta a fertilidade da categoria trabalho, tal como se constrói na teoria marxista, em contraposição ao reducionismo psicologizante que entende a subjetividade nos estreitos contornos da cognição e da inteligência. Corrêa (2000) discute a formação da consciência política em tempos de globalização e neoliberalismo. Em estudo sobre o senso comum dos professores, sob a influência do neoliberalismo, destaca o papel mediador das instituições educacionais na formação do senso crítico, ou acrítico, destes profissionais. Conclui considerando a necessidade da desconstrução da hegemonia do neoliberalismo e, para isto, aposta na ampliação dos espaços públicos, na afirmação da educação como um direito social e no estímulo à participação nos movimentos políticos e sociais.

Outro tema referente à questão do trabalho e educação nos movimentos sociais, a educação do 'cidadão trabalhador' através do programa Telecurso 2000, foi abordado por Andrade (1999). Ao analisar esse programa, destaca que, para além dos objetivos educacionais imediatos, pretende-se também “contribuir para o estabelecimento de um 'clima' propício à construção de um novo padrão de participação político-social dos indivíduos que compõem a população brasileira" (Andrade, 1999, p. 156).

Uma questão emergente, posta pelos pesquisadores militantes dos movimentos sociais, é a afirmação dos movimentos como princípio educativo. Essa questão tensiona o GT, que tem o trabalho, na sua dimensão ontológica e fundamental de produção da vida e da cultura, como princípio educativo. 
A área vem caracterizando a relação entre trabalho e educação nos movimentos sociais mais como expressão de organização sindical dos trabalhadores do que formas mais autogestionárias. No período mais recente estudado, esse quadro não se modifica. Para além da organização sindical, são investigadas as ações de resistência no âmbito das próprias comunidades escolares, através de ações coletivas de resistência, sobre as quais temos pouca informação.

O único trabalho que se debruça sobre outros movimentos sociais é o de Vendramini (2003), que analisa o MST e reflete sobre a identidade coletiva construída historicamente por seus participantes no contexto das ocupações, a partir da década de 1980.

Os poucos estudos apresentados no GT nos últimos anos sobre as questões do trabalho numa perspectiva dos movimentos sociais remetem ao alerta feito por Frigotto (1998), quando ele propugna por mais pesquisas que investiguem os processos educativos que emergem das lutas dos trabalhadores para além da lógica do capital. No entanto, sabemos que pesquisas produzidas nessa temática são apresentadas em outros fóruns de discussão ou são encaminhadas para outros GTs. Temos por hipótese que o número reduzido de estudos que são selecionados anualmente para apresentação no GT (cerca de 12) e o maior interesse em outros grupos temáticos e referenciais teóricos diferentes do marxismo podem explicar, ao menos em parte, o fenômeno.

\section{Educação do trabalhador nas relações sociais de produção}

Os trabalhos apresentados nesta categoria ocupam-se prioritariamente das transformações no mundo da produção e suas consequências para a educação do trabalhador, questões que ganharam força a partir de 1990, com as políticas de reestruturação produtiva para maior competitividade econômica, no contexto da abertura do mercado brasileiro para o capital internacional.

Em estudo mais abrangente do que os apresentados nas reuniões anuais da Anped, Shiroma e Campos (1997) fazem um balanço das pesquisas em educação sobre o tema qualificação e reestruturação produtiva, sinalizando as preocupações dos pesquisadores no período aproximado de uma década. São colocados em debate os temas: politecnia e polivalência, inovação nos sistemas de produção e demanda por qualificações, centralidade da educação básica, qualificação e competências e suas implicações para a empregabilidade.

As autoras observam um aspecto que também está presente no GT Trabalho e Educação: “a redescoberta da educação nas agendas de empresários e governo" (Shiroma e Campos, 1997, p. 22), a que se deve acrescentar, também dos trabalhadores em meados dos anos 1990, através de suas principais entidades representativas. Esse fato sinaliza o que foi interpretado como projetos 
educacionais de formação profissional em disputa, desde meados dos anos 1980, particularmente a partir da Constituinte de 1988, articulando a seus interesses de classe concepções, processos e conteúdos educativos, gestão de programas e recursos financeiros.

Deluiz (1996) documenta cronologicamente como empresários e trabalhadores organizaram comissões, estudos e debates em torno da automação, da nova organização do trabalho e das novas exigências de qualificação. E mostra que produtividade e eficiência são desafios estratégicos que incluem, na agenda empresarial, as novas competências e, na agenda dos trabalhadores, a gestão tripartite das agências de formação profissional (o Sistema S) e a vinculação entre educação geral e formação profissional.

Tumolo (1998) apresenta uma revisão bibliográfica crítica sobre o tema, a partir de áreas afins com a educação: sociologia do trabalho, economia do trabalho, economia política, administração de empresas, educação e trabalho, engenharia. Conclui que "a intensificação da exploração sobre a força de trabalho significa uma tendencial redução nas possibilidades de implementação de propostas alternativas por dentro da ordem capitalista (...)" (Tumolo, 1998, p.15).

O tema da educação dos trabalhadores face às novas exigências da reestruturação produtiva em curso está presente de 1996 a 2001, embora com incidência progressiva em relação à compreensão do saber dos trabalhadores e às políticas de formação. Empresários e trabalhadores foram entrevistados por Zibas (1996) para verificar as exigências de qualificação postas por algumas empresas industriais que teriam adotado com sucesso novas técnicas organizacionais denominadas 'administração participativa'. O êxito das empresas de 'produção enxuta' em garantir produtividade a menor custo também se faz presente na adesão dos trabalhadores entrevistados. Minimiza-se o "histórico conflito que sempre se desenvolveu no local de trabalho entre empresários/gerentes ou chefes e trabalhadores" (Zibas, 1996, p. 15).

Dos 11 trabalhos apresentados em 1997, quatro dão continuidade à discussão de questões similares. Markert (2002a) trata da reorganização da produção, do novo perfil do trabalhador para o trabalho em grupo, da requalificação e do modelo de cooperação entre departamentos. A pesquisa foi realizada na Alemanha, em empresas que iniciaram o processo de ilhas de produção, com a implantação do modelo acompanhada da oferta de qualificação aos trabalhadores.

Araújo (1997) estudou uma empresa que introduziu novas tecnologias organizacionais associadas ao paradigma da produção flexível integrada. Entrevistou trabalhadores, supervisores e gerentes da filial de uma multinacional, examinando as técnicas de organização do trabalho (CCQ, células de fabricação, 'kanbam', just in time etc.) pelas quais são valorizadas as chamadas 'características pessoais', em detrimento dos saberes profissionais. 
Martins (1997) estudou o processo de Qualidade Total na Cia. Cervejaria Brahma, a qual passava por uma modernização técnico-gerencial e instituiu um campo pedagógico na empresa através do sistema learning organization. $\mathrm{O}$ autor assinala que "a instrumentalização de recursos pedagogizantes extrapola o espaço do treinamento para assumir a forma de um verdadeiro movimento social (...)" (Martins, 1997, p. 126).

A partir das novas exigências de escolarização dos trabalhadores, introduzidas pelas empresas, Souza (1997) examina uma localizada na Bahia que implantou um programa de complementação de escolaridade dos funcionários (da alfabetização ao $2^{\circ} \mathrm{Grau}$ ), em parceria com a Secretaria de Educação do Estado. Os resultados indicam a satisfação dos dirigentes da empresa quanto à adequação da mão-de-obra à modernização tecnológica. Os trabalhadores têm novas oportunidades de conhecimento e aspiram à continuidade dos estudos. Destaca-se uma dificuldade: o alto índice de retenção dos alunos pelas condições de estudo e pelas situações pessoais.

Trabalho instigante foi apresentado por Bianchetti (1998), buscando aproximar a compreensão das novas tecnologias e a apropriação do saber tácito dos trabalhadores. O autor observa como as Tecnologias de Informação (TICs) permitem uma 'visibilidade das competências' ou um processo de 'devassamento' de saberes, cujas consequências ainda demandam esclarecimentos.

Francisca Andrade (1998) estudou estratégias de formação de recursos humanos de empresas automobilísticas alemãs implantadas no Brasil (subsidiárias da Mercedes-Benz e da Daimler-Benz), visando a compreender seus efeitos sobre a qualificação dos trabalhadores. Um dos resultados principais da pesquisa revelou o investimento das empresas no treinamento e na capacitação profissional dos trabalhadores e, muitas vezes, de seus familiares e da comunidade da região onde se situa a fábrica.

Buscando particularizar as relações entre a empresa e os trabalhadores no novo contexto da produção, Corrêa e Teixeira (2000, p. 15) analisaram os "processos de conformação da subjetividade política" de trabalhadores de uma empresa automobilística multinacional através da educação profissional e de procedimentos participativos no interior desta empresa e da "internalização das formas de controle características das relações de poder capital-trabalho (...) de uma forma aparentemente menos coercitiva, mais persuasiva e sedutora".

Invernizzi (2000, p. 15) realizou um amplo trabalho de análise de pesquisas realizadas durante as décadas de 1980 e 1990 em seis indústrias de ramos diversos, examinando quatro aspectos que influenciam a qualificação do trabalho: modernização tecnológica; novos métodos organizacionais; novos enfoques de gestão de recursos humanos; e relações industriais e impactos sobre os trabalhadores, "com maior controle e disciplinamento".

Alguns autores buscam conhecer o contraponto desses processos junto aos trabalhadores ou através de suas entidades representativas. Tumolo 
(1997) discutiu a formação sindical na Central Única dos Trabalhadores (CUT), a partir do novo padrão de acumulação, e o impacto das mudanças no mundo do trabalho e no sindicalismo. A CUT estaria incorporando o novo padrão de sindicalismo, a "tendência da passagem de um sindicalismo de confrontação para um sindicalismo de negociação, de concertação" (Tumolo, 1997, p. 10).

Os pesquisadores participantes do GT buscam conhecer, também, o que pensam os trabalhadores através de suas principais entidades representativas sobre o papel da educação face às transformações no mundo do trabalho, a exemplo de Souza, Santana e Deluiz (1999).

Em uma subcategoria mais geral situam-se o estudo de Gentili apresentado em 1997 e o ensaio de Arrais Neto, em 1999. Gentili examina o desenvolvimento capitalista diante da crise global e a desintegração da escolaridade, com o fim da 'promessa integradora' através da educação, do pleno emprego e da empregabilidade. Por sua vez, Arrais Neto (1999) discute o que considera equívocos de interpretação do papel da educação em face da nova divisão internacional do trabalho, que sinaliza o retorno da teoria do capital humano e a ilusão da conquista da empregabilidade pela formação como recurso ao desemprego.

No período analisado anteriormente - 1996 a 2001 -, verificamos que o processo em curso durante toda a década de 1990 de reestruturação produtiva foi acompanhado de fortes mudanças na gestão e também nas novas exigências em relação à formação dos trabalhadores, o que mobilizou os pesquisadores do GT a investigarem como os diversos sujeitos sociais vivenciam esse processo. Foram analisadas as propostas empresariais, as políticas públicas, as ações dos sindicatos e a disputa pelos recursos do FAT no oferecimento de cursos de escolarização básica e profissional.

No período em foco, 2002 a 2007, verificamos que se sedimentou o processo em curso e as políticas dos empresários e do governo convergiram pragmaticamente permeando todosos espaços que pareciam ainda em disputa. À exceção de alguns segmentos de trabalhadores, os próprios sindicatos foram sendo cooptados para as propostas governamentais, o que contribuiu para desarticular ainda mais os espaços de resistência e de construção de propostas contra-hegemônicas.

Os trabalhos atuais apresentados no GT priorizam as consequências da lógica mercantilista da empregabilidade e do empreendedorismo que se instalou na base produtiva da sociedade e em todos os níveis educacionais.

Ao analisar a atuação dos empresários do ensino na reforma da educação superior empreendida pelo governo Lula, Rodrigues (2006) elucida as contradições existentes no seio da própria burguesia quando encara a educação escolar como 'educação-mercadoria' e como 'mercadoria-educação' . Para o autor, o Estado gerencia através das políticas públicas os conflitos 
dessas frações de classe, ou seja, busca contemplar tanto os interesses dos empresários da educação quanto os da burguesia industrial. Também Delgado (2006) vai analisar a interação universidade-empresa sob a ótica da Confederação Nacional da Indústria (CNI) e as demandas empresariais por pesquisa aplicada e por formação profissional adequada ao mercado.

\section{Profissionalização e trabalho}

A temática da profissionalização vem ganhando vulto nos estudos empíricos realizados nos últimos anos e envolve as mudanças nos processos produtivos e o novo perfil profissional exigido dos trabalhadores. Destacamos anteriormente (Trein e Ciavatta, 2003) duas estratégias de abordagem da questão: conhecer o pensamento das agências formadoras, e assim chegar ao trabalhador, e tentar apreender, a partir do próprio trabalhador inserido no processo produtivo, quais as questões de seu interesse no que diz respeito à profissionalização e o mundo do trabalho. As abordagens apresentadas no GT, nos últimos cinco anos, têm, em sua maioria, enfatizado a primeira estratégia. A forma como isso se deu será analisada a seguir.

Alguns estudos de recorte comparativo permitem acompanhar o desenvolvimento da questão em outros países. Gentili (1998) refere-se especificamente ao caso argentino, mas sinaliza uma tendência no mundo globalizado, marcado por crescente retração do Estado nas políticas de formação profissional, e influência acentuada dos parâmetros produtivistas da lógica empresarial no âmbito dos espaços formativos. Leher (1999) volta-se para as questões relativas às políticas do Banco Mundial e seus impactos na América Latina. Para ele, as conexões entre educação, segurança e pobreza constituem-se no mote para orientar políticas públicas.

No âmbito das políticas educacionais voltadas à formação profissional face à globalização e às novas formas de organização do trabalho, Ciavatta Franco (1998b) apresentou um estudo comparativo de três países - México, Brasil e Itália. Os principais aspectos abordados foram: a ressignificação da formação dos trabalhadores; a formação profissional como moeda de negociação no México; a formação para a atenuação do desemprego na Itália.

Por sua vez, Hopstein (1999), ao analisar a realidade argentina e a reforma do Estado proposta pelos organismos internacionais, conclui que o verdadeiro papel que ocupa a capacitação profissional do setor público é o de obter o consenso e o compromisso dos servidores públicos na implementação das políticas de reforma estrutural do Estado. No trabalho de Fidalgo (1999), são analisadas as experiências da França e do Brasil no que diz respeito às tendências de profissionalização dos trabalhadores e como estas vêm sendo negociadas de forma tripartite. 
Também Rodrigues (1998), discutindo a perspectiva teleológica do empresariado brasileiro em diferentes momentos da história, destaca que o horizonte da formação proposta pelo empresariado é o mercado, enquanto a educação que serve aos interesses dos trabalhadores é a formação humana 'omnilateral'.

Para Ramos (1996, p. 149), as políticas públicas para a profissionalização objetivam “a redução significativa de seus custos e implementação de programas de capacitação de massa em detrimento da formação profissional plena e integrada ao nível médio".

A pesquisa de Soares (1999) também corrobora essas observações e enfatiza que o ensino de jovens e adultos não tem lugar próprio no cenário educacional brasileiro. O que se observa é um mercado de trabalho excludente onde o discurso da empregabilidade, mesmo para aqueles com elevado 'capital humano', já demonstrou ser falacioso.

Santos (2002) vai discutir o novo Ensino Médio à luz da relação trabalho e educação, destacando que as pretensas liberdade e flexibilidade curricular apontariam para uma educação mais adequada a cada camada social. Para a autora, como os mecanismos avaliativos denunciam, entre eles o Exame Nacional do Ensino Médio, há aí uma evidente exclusão social e de classe.

Já Tomas e Laudares (2002), analisando os Cefets, indicam que as mudanças advindas das novas exigências do mercado são redefinidoras do perfil profissional dos trabalhadores de nível médio. Este já não estaria atendendo às necessidades das grandes empresas, que passam a requisitar tecnólogos de nível superior.

Na contramão dessa tendência, que se materializa nas propostas do governo federal e dos empresários, é estudada a experiência da Escola Politécnica de Saúde Joaquim Venâncio, da Fundação Oswaldo Cruz, no Rio de Janeiro. $\mathrm{Na}$ análise desse caso concreto, Amâncio Filho (2002) questiona a possibilidade de implantação de uma proposta de profissionalização no marco teórico da educação politécnica e da formação humana 'omnilateral', examinando os entraves, as possibilidades e as contradições do processo.

Nos estudos analisados, pudemos constatar o pensamento das agências formadoras e, a partir dele, chegar à compreensão da educação e da profissionalização que são oferecidas aos trabalhadores. No entanto, a outra estratégia apontada por Kuenzer (1987), que é a compreensão ampliada da questão da profissionalização a partir dos próprios trabalhadores inseridos no processo produtivo, é uma perspectiva que ainda carece de novos esforços de pesquisa.

Como já foi enfatizado anteriormente, essa temática está cada vez mais presente no GT, dadas as novas demandas do capital no que diz respeito à formação da força de trabalho - os 'colaboradores' no eufemismo da produção flexível - desregulamentada nos processos produtivos e nas relações de trabalho. Os trabalhos mais recentes (2002-2007) vêm priorizando, em 
suas análises, as propostas das agências formadoras sob o impacto das políticas propostas pelos organismos internacionais, hoje fortemente incorporados não apenas nos espaços de formação profissional de nível médio, mas também no ensino superior. Por isso, principalmente depois de 2004, diversos trabalhos analisam os impactos da pedagogia das competências, também nas universidades, como uma das novas faces da teoria do capital humano.

Permanece, no entanto, o alerta de Kuenzer (1987), quando demandava novos esforços de pesquisa que dessem conta da vivência dos próprios trabalhadores, inseridos na produção, sobre a profissionalização numa compreensão mais ampliada da questão. Os trabalhos empíricos apresentados no GT buscam detectar de que forma as escolas técnicas estão vivenciando concretamente essas orientações. Também em entrevistas com trabalhadores, tanto do setor industrial quanto de serviços, verificam quais os impactos da lógica da gestão empresarial voltada para o mercado de trabalho, hoje com menos eufemismos (a exemplo de cidadania) do que anteriormente.

Chama a atenção a ausência de trabalhos referentes à realidade mundial em geral e latino-americana em particular. O que parece estranho, considerando que há muito tempo, no Brasil, não se falava tanto na América Latina e nos problemas comuns aos nossos países. Talvez a percepção das especificidades da realidade brasileira ainda não tematizadas suficientemente, por um lado, e as exigências cada vez mais aceleradas de tentar equacionar os problemas cotidianos, por outro, dificultam que os pesquisadores tentem articular a compreensão de suas lutas diárias com o que se passa no continente.

Entre 2002 e 2007, foram aprovados 103 trabalhos no GT, dentre os quais $38(36,9 \%)$ podem ser classificados como diretamente ligados à temática da reforma da educação profissional e seus desdobramentos. Essa preocupação não é nova na área. Já em 1987, o trabalho de Dermeval Saviani, intitulado Sobre a concepção de politecnia, suscitou debates e publicações sobre a relação Ensino Médio e técnico numa perspectiva crítica em que se buscava, pela afirmação de uma educação omnilateral, baseada na educação politécnica, enfrentar a dualidade estrutural que marca a educação brasileira ao longo de sua história.

Em 2005, José Rodrigues lamenta que nem mesmo com a aprovação do decreto n. ${ }^{\circ}$ 2.208/97 - no governo Fernando Henrique Cardoso - que veio desvincular a formação geral de Ensino Médio técnico da educação profissional, o debate sobre a politécnica e a educação omnilateral tenha sido retomado (Rodrigues, 2005). Será apenas com a revogação desse decreto e a alternativa da formação integrada entre a formação geral e a educação profissional, técnica e tecnológica no Ensino Médio técnico, pelo decreto n. ${ }^{\circ}$ 5.154/04 - no governo Lula -, que se explicita a dimensão polêmica envolvida nas reformas presentes nos dois decretos (Rodrigues, 2005; Frigotto, Ciavatta e Ramos, 2005). 
A análise da produção do GT aponta que, embora tenha ocorrido um período entre a promulgação do decreto e a sistematização das pesquisas sobre os seus resultados, a temática permaneceu latente. Consideramos que a correlação de forças que permaneceu desfavorável à esquerda organizada durante o segundo mandato do presidente Fernando Henrique Cardoso não permitiu um enfrentamento maior da questão. Os educadores vão obter a revogação do decreto n. ${ }^{\circ} 2.208$ em 2004, quando o presidente Luiz Inácio Lula da Silva cumpre um compromisso de campanha e exara o decreto n. ${ }^{\circ} 5.154 / 04$.

É justamente nesse período que se fazem sentir os efeitos dos embates teóricos e políticos em torno do tema. Vários trabalhos apresentados no GT esmiúçam a problemática sob diversos ângulos. Na reunião anual da Anped de 2004, dos 19 trabalhos aprovados no GT Trabalho e Educação, 11 se debruçam especificamente sobre a reforma do Ensino Médio técnico, em relação aos planos referentes à qualificação profissional, tanto os nacionais quanto os estaduais.

Andrade (2004) analisa a reforma do Ensino Médio buscando identificar o perfil comportamental prescrito e como este objetivo ganha concretude através de uma adequação curricular que permita a articulação mais direta entre a formação do Ensino Médio e as demandas empresariais de um trabalhador 'eficiente para o capital'.

Já em Cêa (2004) encontramos uma avaliação do Planfor e do Plano Nacional de Qualificação (PNQ) como política pública mediada pela reforma gerencial do Estado brasileiro e pela privatização do fundo púbico, no caso o FAT. A pesquisa evidenciou o financiamento público da reprodução flexível do capital como forma de atuação do Estado neoliberal.

Na mesma direção, Franzoi (2004) investiga o Plano Estadual de Qualificação do Estado do Rio Grande do Sul (PEQ-RS), que tem como conceito de profissionalização a articulação entre conhecimento e mercado de trabalho. A pesquisa com os egressos evidenciou, no entanto, que os beneficiados são os que já possuíam uma trajetória bem-sucedida, mas não para os que não tinham uma profissão e dependiam de outros instrumentos que articulassem formação e inserção no mercado de trabalho. Também em Gonzalez e Matias (2004) encontramos uma abordagem crítica quanto às ações de educação profissional realizadas por ONGs no município do Rio de Janeiro, com recursos do FAT. Os autores concluem que as diretrizes pedagógicas dos cursos mostravam a falta de clareza dos implementadores quanto aos conceitos de competências e habilidades, que eram centrais na legislação que regulamenta o uso dos recursos do FAT no âmbito do Planfor.

Já no processo de discussão do decreto n. ${ }^{\circ} 2.208 / 97$ durante o Seminário Nacional sobre Educação Profissional (MEC/Semtec, em 2003), Oliveira (2004) questiona até que ponto a nova proposta que embasou o decreto 
n. ${ }^{\circ}$ 5.154/04, em discussão, abandona o viés produtivista do decreto n. ${ }^{\circ}$ 2.208/97. Osório e Leão (2004), em uma perspectiva foucaultiana, analisam os pressupostos do PNQ (2003) e do Plano Nacional de Educação Profissional (1998), concluindo que as definições das políticas públicas partem de pressupostos apaziguadores dos conflitos sociais, não evidenciando um compromisso coletivo para superar com radicalidade as 'dificuldades socialmente conflitivas'.

Em 2005, vários trabalhos investigam de que forma o Ensino Médio e o Ensino Superior são impactados tanto pelas mudanças curriculares e a efetivação ou não da pedagogia das competências quanto pelas consequências do chamado 'choque de gestão' nas instituições educacionais. Também são analisadas as formas de resistência dos docentes a essas situações adversas para o desempenho profissional, que se expressam em precarização das condições de trabalho, sobretrabalho, fragmentação, adoecimento etc. Indicam também a necessidade de acompanharmos mais detidamente os processos em curso no país e o protagonismo dos professores, tanto na implantação quanto na resistência às reformas (Búrigo, 2005).

Suhr (2005), levando em conta a posição de empresas de recursos humanos, portanto do mercado, e de jovens egressos do Ensino Médio, conclui que a pretensa articulação entre ensino e mercado de trabalho não se efetiva; não aumenta as possibilidades de inserção no mercado de trabalho, nem viabiliza que os jovens ampliem sua compreensão da realidade.

Também Cêa (2006) investiga os sentidos assumidos pela educação profissional a partir da reforma dos anos 1990 e as condições de implementação dos cursos de Ensino Médio integrado. Para a autora, a revogação do decreto n. ${ }^{\circ}$ 2.208/97 não significou a superação da continuidade da hegemonia da educação profissional desintegrada.

Um aspecto relevante, mas pouco tematizado no GT, é a questão do financiamento da educação. Oliveira (2007) analisa a necessidade da modificação do financiamento do Ensino Médio, de forma a garantir a articulação entre a formação técnica e a formação geral. Ele adverte que os recursos do Fundo de Manutenção e Desenvolvimento da Educação Básica e de Valorização dos Profissionais da Educação (Fundeb) não serão suficientes para o financiamento da última etapa da educação básica.

No período investigado, de 2002 a 2007, principalmente no que diz respeito ao Ensino Médio integrado, algumas questões recorrentes ficam em aberto: a) qual a possibilidade de pensarmos em uma educação politécnica sob o modo de produção capitalista?; b) em que medida as reformas educacionais, baseadas na pedagogia das competências, foram efetivadas nas escolas e qual o espaço para ações de resistência dos professores a um modelo que retoma, em suas bases, a teoria do capital humano? 


\section{À guisa de conclusão}

Do percurso empírico e teórico-metodológico do presente trabalho, destacamos algumas questões mais gerais:

1. O GT Trabalho e Educação mantém no seu horizonte

a necessidade de desenvolver o corpo teórico da área, através de um concentrado esforço de reflexão sobre os fundamentos teórico-metodológicos da relação entre trabalho e educação, atentando para os perigos da manipulação de conceitos gerais como se fossem uma substantividade própria, independentemente de tempo e lugar (Kuenzer, 1987, p. 93).

Essa base teórica no materialismo histórico traz consigo outro traço distintivo do GT: a visão política pautada pelo compromisso com a transformação das formas de exploração e amesquinhamento do ser humano, geradas pela produção e pela sociabilidade do capital. Tem prevalecido, contudo, o diálogo e o confronto com autores que questionam o marxismo ou que trazem contribuições analíticas pautadas por temas emergentes no contexto das transformações do último século, tais como a sociedade de consumo, a comunicação, a subjetividade, a presença da imagem e o ideário pós-moderno.

2. Por ser uma área de estudos ligada às relações entre o capital e o trabalho, as transformações socioeconômicas e políticas precisam ser reconhecidas e estudadas. Trata-se de compreender o campo empírico onde as pesquisas se realizam (empresas, escolas, movimentos sociais), as categorias e os conceitos privilegiados pelos diversos autores em seus trabalhos e o sentido político das análises desenvolvidas. Entendemos que os mundos do trabalho e da educação possam ser mais bem apreendidos a partir das categorias do materialismo histórico, particularmente, trabalho, totalidade, mediação e contradição.

3. O GT Trabalho e Educação, tanto nos trabalhos de caráter teórico quanto nos mais empíricos, tem feito uma crítica radical ao ideário neoliberal, ao 'fim da história' e às propostas de ajustamento ou acomodação passiva dos trabalhadores às exigências da reestruturação produtiva e da nova organização do trabalho. Entretanto, não tem tematizado suficientemente as alternativas de concepção e de ação para a construção de uma nova sociedade. Quais as propostas que emergem da sociedade brasileira e que se contrapõem ao modelo vigente? Que tipo de desenvolvimento estaria contido nas propostas que vêm sendo elaboradas pelos trabalhadores através do movimento social organizado (sindicatos, MST, administrações municipais de corte democrático popular)?

4. De que educação básica e de que educação os trabalhadores estão falando quando reivindicam mais educação e formação profissional? O que 
sugere a necessidade de mais estudos no interior das empresas e das escolas submetidas, com maior ou menor adesão, às reformas do Ensino Médio, profissional e técnico através dos cursos modulares, do ensino à distância $\mathrm{e}$ da formação de tecnólogos?

5. Os estudos historiográficos, com documentação de época, remetem à memória de um passado que ajuda a compreender o presente e a projetar o futuro. Eles são escassos no GT, seja pela urgência dos problemas do mundo do trabalho no presente, seja pela insuficiência de tempo, de recursos e de formação. A compreensão da história como produção da existência (Marx, 1979), em todos os seus aspectos, é parte da obra marxiana tanto quanto os conceitos mais gerais da crítica à economia política.

6. Outra questão diz respeito aos canais de comunicação entre o meio acadêmico e a sociedade civil, os sindicatos particularmente. Em relação aos trabalhadores, a realidade é outra. Não tem ocorrido o que, em outros países, viabilizou a elevação da formação geral, não somente no que se refere ao nível de qualificação profissional, mas também de formação política, viabilizado pela existência de universidades populares e de outras formas alternativas de ensino.

7. Hoje, as universidades públicas possuem significativo acervo de conhecimentos e um potencial de recursos pedagógicos que permitem viabilizar formas de cooperação mais estreitas entre as universidades e os trabalhadores. Isso poderia se dar em três níveis: documentação, formação e pesquisa. O acervo de pesquisas na área Trabalho e Educação existente nas universidades públicas é ainda insuficientemente socializado. E haveria uma pauta de questões que podem contribuir para que a cultura, a educação e a formação profissional, financiadas pelo fundo público, deixem de ser apropriadas por poucos. A experiência de tratamento documental desse acervo pode ajudar no trabalho de organização dos conhecimentos gerados pelos sindicatos. Poderia, ainda, auxiliar na preservação da memória do trabalho e dos trabalhadores, fonte de identidade de classe, de projetos de futuro e de resistência nas lutas do presente. Na área de formação, as demandas dos trabalhadores poderiam ser atendidas através das atividades de extensão, cursos de pós-graduação lato sensu, consultoria e encontros programados nas universidades, nos sindicatos e nas escolas de formação profissional e técnica.

8. Se isso é verdade, sugerimos a elaboração de uma pauta de atividades de extensão que viabilize a interlocução dos pesquisadores com os sindicalistas e professores das escolas profissionais e técnicas. Mas essa não seria apenas uma atividade pontual, seletiva, e sim um projeto com linhas comuns de ação política e de permanente avaliação para a correção de rumos.

9. Quanto à formação do educador no nível da graduação, é importante permear os estudos pedagógicos com a visão do mundo do trabalho, que tem recebido uma demanda crescente de estudos voltados para o exercício 
profissional do professor. Seria o caso de se pensar sobre a inclusão da temática Trabalho e Educação na grade curricular dos cursos de pedagogia e nas licenciaturas.

10. Do ponto de vista da interlocução sobre o mundo do trabalho com outras áreas do conhecimento, observamos as aproximações recorrentes com a economia, a história, a sociologia e, em menor proporção, com a ciência política e a comunicação. Sugerimos conhecer os estudos que a área da saúde tem desenvolvido sobre as condições de trabalho no mundo atual e suas consequências na saúde dos trabalhadores, a exemplo das pesquisas sobre a psicopatologia do trabalho (Dejours, 1992), insalubridade (Rebouças, 1989), 'doenças dos nervos' (Duarte, 1986), fadiga, distúrbios do sono, estresse ou síndrome de burnout (Codo, 1999), e angústia e insatisfação no ambiente de trabalho, a chamada síndrome loco-neurótica (Alevato, 1999).

11. Um tema ausente nas discussões do GT é 'a nova ética protestante', que parece estar crescendo na sociedade brasileira, já presente nas propostas de formação que emanam do setor empresarial. Essas se caracterizam pelos ethos do trabalhador disciplinado, empreendedor, ordeiro, parceiro do patrão na nova organização do trabalho. O que parece estar sendo reforçado pelas ideologias religiosas das novas igrejas de denominação 'evangélica' que têm reintroduzido o 'creacionismo' 13 com o apoio público, como no caso do estado do Rio de Janeiro.

12. Não obstante o crescimento do número de trabalhos sobre o Ensino Médio técnico e as reformas educacionais, estes estão centrados nos efeitos da implantação autoritária do decreto n. ${ }^{\circ}$ 2.208/97. Faltam pesquisas acerca das ações de resistência nas escolas e sobre as iniciativas pautadas na alternativa da formação integrada aberta pelo decreto $n{ }^{\circ} 5.154$ e a manutenção das matrículas concomitantes e subsequentes, tanto na rede das escolas federais quanto nas redes de Ensino Médio dos estados. 


\section{Notas}

1 Professora Associada da Faculdade de Educação da Universidade Federal Fluminense (UFF). Doutora em Educação pela Universidade Federal do Rio de Janeiro (UFRJ). < eunicetrein@ig.com.br> Correspondência: Rua Pacheco Leão, 704, bloco A, casa 2, Jardim Botânico, Rio de Janeiro, Brasil, CEP 22460-030.

2 Professora Titular-Associada ao Programa de Pós-Graduação em Educação da UFF e Professora Visitante da Faculdade de Serviço Social da Universidade do Estado do Rio de Janeiro (Uerj). Doutora em Ciências Humanas (Educação, PUC-RJ). Pós-doutorado em Sociologia do Trabalho pela Università di Bologna, Itália.<mciavatta@terra.com.br>

3 Esta introdução retoma os textos de Ciavatta (2007a e 2007b).

4 Como bem assinala Falcon (2006).

5 Em termos breves, buscar a historicidade da produção científica do GT significa situá-la no contexto dos seus vínculos com a sociedade capitalista em que vivemos, como acontecimentos e seus significados, no âmbito da instituição onde ocorrem, o GT Trabalho e Educação da Anped (Ciavatta, 2007a e 2007b).

6 Complementarmente, registramos as indicações metodológicas dos seguintes trabalhos: Franco e Baeta (1985) e Wittman e Gracindo (2001).

${ }^{7}$ Este ensaio retoma e atualiza a pesquisa realizada anteriormente sobre o período de 1996 a 2001 (Trein e Ciavatta, 2003), analisando a produção científica do GT Trabalho e Educação no período de 2002 a 2007.

8 Para um detalhamento do perfil do GT desde sua criação, ver a introdução de nosso trabalho anterior (Trein e Ciavatta, 2003).

9 A autora, em sua tese de doutorado sobre o tema, trabalha com a noção de gênero do discurso de Mikhail Bakhtin (1997) e com a noção de suporte material a partir de Chartier (1996) e, finalmente, a noção de rede, questões que não discutiremos neste trabalho (ver Ferreira, 2002, p. 267-270).

10 Para um maior detalhamento da trajetória histórica do GT, ver Trein e Ciavatta (2003, p. 140-164). Ao longo do tempo, o GT passou por diversas coordenações. A primeira foi de Jacques Velloso (1981-1982), seguido de Miguel Arroyo e Gaudêncio Frigotto (19821988). Em 1987, na $10^{a}$ Reunião Anual, implantou-se a experiência da coordenação colegiada, incluindo-se Nilton Fisher. Na $11^{\text {a }}$ Reunião Anual, a coordenação foi assumida por Gaudêncio Frigotto, Paulo Nosella e Iracy Picanço (1988-2000). Algumas dificuldades operacionais fizeram com que as coordenações seguintes fossem assumidas por apenas uma pessoa com a colaboração informal de outros colegas. Assim, sucederam-se na coordenação Iracy Picanço (1991-1993), Eunice Trein (1994-1996), Celso Ferretti (1997-1998), Lucília Machado (1999-2000), Paulo Tumolo (2001-2002), Maria Ciavatta (2003-2004), Marlene Ribeiro e Domingos Leite Filho (2005-2006), Ronaldo Lima e Paolo Nosella (2007-2008).

11 Nesta seção, sintetizamos apenas as ideias principais dos trabalhos, apresentados de forma mais argumentativa no primeiro texto (Trein e Ciavatta, 2003). 
12 A questão teórico-metodológica na área trabalho e educação também é objeto de um tópico de análise em Castilho e Pereira (2003), tomando por base a Revista do Núcleo de Estudos sobre Trabalho e Educação (Nete), da Universidade Federal de Minas Gerais (UFMG), de 1997 a 2001. A resenha dos artigos publicados no período evidencia pluralidade temática e de referenciais teóricos.

13 Não se trata de interferir na vida pessoal, religiosa dos alunos, mas de atentar para o fato de que, primeiro, somos um Estado laico; segundo, há um século e meio, a ciência vem corroborando os principais aspectos da teoria de Darwin sobre a evolução das espécies.

\section{Referências}

ALEVATO, Hilda. Trabalho e neurose; enfrentando a tortura de um ambiente de crise. Rio de Janeiro: Quartet, 1999.

AMÂNCIO FILHO, Antenor. Limitantes para uma educação politécnica na saúde. In: Anped, 25 anos. CD-ROM histórico, 2002.

ANDRADE, Flávio Anício. (Com)formação para um trabalho competente: a reforma do ensino médio no Brasil (1998-2002). Trabalho apresentado na 27 $7^{a}$ Reunião Anual da Anped. CD-Rom, 2004.

A formação do 'cidadão-trabalhador': educação e cidadania no contexto do 'novo industrialismo'. Trabalho apresentado na $21^{\text {a }}$ Reunião Anual da Anped. In: Anped 25 anos. CD-Rom histórico, 2002.

Educação sem distância; as demandas da produção e uma proposta formativoempresarial: o programa Telecurso 2000. Trabalho \& Crítica, n. 1, p. 147-159, 1999.

ANDRADE, Francisca R. B. As empresas automobilísticas e suas estratégias de formação de recursos humanos: a referência da Volskswagen e da Mercedes Benz do Brasil. Trabalho apresentado na $21^{\text {a }}$ Reunião Anual da Anped. In: Anped 25 anos. CD-Rom histórico, 2002.
ANPED. Anped 25 anos - sistemática de avaliação de trabalhos, 'posters' e minicursos. Boletim da Associação Nacional de PósGraduação e Pesquisa em Educação, n. 3, p. 8, 2002.

ARAÚJO, Liana Brito de C. A questão do método em Marx e Lukács: o desafio da reprodução ideal de um processo real. Trabalho apresentado na $25^{\mathrm{a}}$ Reunião Anual da Anped. CD-Rom, 2002.

ARAÚJO, Ronaldo M. de L. As novas 'qualidades pessoais' requeridas pelo capital. Trabalho apresentado na $20^{\mathrm{a}}$ Reunião Anual da Anped. In: Anped 25 anos. CD-Rom histórico, 2002.

ARRAIS NETO, Enéas de A. Educação para uma sociedade de alta qualificação profissional: os equívocos da busca de competitividade sob a nova divisão internacional do trabalho. In: Programa e resumos. $22^{\mathrm{a}}$ Reunião Anual da Anped - Diversidade e desigualdade: desafios para a educação na fronteira do século. Caxambu, 26 a 30 set. 1999.

AZEVEDO, Janete M. L. de; AGUIAR, Márcia A. A produção do conhecimento sobre a política educacional no Brasil: um olhar a partir da Anped. Educação e Sociedade, n. 77, p. 49-70, dez. 2001. 
BAKHTIN, Mikhail. Estética da criação verbal. São Paulo: Martins Fontes, 1997.

BIANCHETTI, Lucídio. As novas tecnologias e a devassagem do espaço-tempo do saber tácito dos trabalhadores. Trabalho apresentado na $21^{\text {a }}$ Reunião Anual da Anped. In: Anped 25 anos. CD-ROM histórico, 2002.

BOMFIM, Alexandre Maia do. Há 21 anos 'Educação e Trabalho' transformou-se em 'Trabalho e Educação': da construção da identidade marxista aos desafios da década de 90 pelo GT TE da Anped. In: Anped: 30 anos de pesquisa e compromisso social, 2007. Caxambu, CD-ROM, 2007.

BONFIM, Antonio Carlos Ferreira. Habermas: trabalho, linguagem e forma de vida humana. Trabalho apresentado na $25^{a}$ Reunião Anual da Anped. CD-ROM, 2002.

BOURDIEU, Pierre. Le champ cientifique. Actes de Recherche en Sciences Sociales, n. 2/3, 1976, apud Azevedo e Aguiar, 2001, p. 50.

BÚRIGO, Elisabete Zardo. Professores, técnicos ou engenheiros? Identidades profissionais face à reforma do ensino técnico. Trabalho apresentado na 28 ${ }^{\mathrm{a}}$ Reunião Anual da Anped. CD-ROM, 2005.

CASTILHO, Ana Paula L.; PEREIRA, Rosângela Maria. Trabalho e educação: contribuições dos artigos publicados na Revista do Nete. Trabalho \& Educação, v. 12, n. 2, jul./dez. 2003.

CASTRO, Ramon P. Desvalorização real do trabalho e centralidade ilusória da educação. Trabalho apresentado na $21^{\text {a }}$ Reunião Anual da Anped. In: Anped 25 anos. CD-ROM histórico, 2002.

CÊA, Georgia Sobreira dos S. A qualificação profissional como instrumento de regulação social: do Planfor ao PNQ. Trabalho apresentado na $27^{\mathrm{a}}$ Reunião Anual da Anped. CD-ROM, 2004.

A reforma da educação profissional e o ensino médio integrado: tendências e riscos. Trabalho apresentado na $29^{a}$ Reunião Anual da Anped. CD-ROM, 2006.
A relação entre trabalho e educação básica: elementos de um consenso interessado. Trabalho \& Crítica, n. 1, p. 84-97, 1999.

CHARTIER, Roger (Org.). Práticas de leitura. São Paulo: Estação Liberdade, 1996.

CIAVATTA, Maria. Historiografia em trabalho e educação. Como se constroem as categorias. Projeto de Pesquisa. Niterói: UFF, 2007a. Mimeografado.

História e historiografia em trabalho e educação. In: ENCONTRO DE ESTUDOS E PESQUISAS EM HISTÓRIA, TRABALHO E EDUCAÇÃO, 2007b, Campinas. Unicamp: Grupo de Estudos e Pesquisas HISTEDBR, 3 a 5 set. 2007. Mimeografado.

CIAVATTA FRANCO, Maria. O trabalho como princípio educativo: uma investigação teóricometodológica (1930-1960), 1990. Tese de Doutorado, Rio de Janeiro: Pontifícia Universidade Católica.

Formação profissional para o trabalho incerto: um estudo comparativo Brasil, México e Itália. In: FRIGOTTO, Gaudêncio (Org.). Educação e crise do trabalho: perspectivas de final de século. Petrópolis: Vozes, 1998a.

Imagens do mundo do trabalho: a fotografia como fonte histórica. Minicurso. In: REUNIÃO ANUAL DA ANPED - Conhecimento e poder: em defesa da universidade pública, 21, 1998b, Caxambu. Programa e resumos.

CIAVATTA FRANCO, Maria; BAETA, Ana Maria B. Quinze anos de vestibular (19681993): apresentação. Educação e Seleção, n. 12, p. 5-8, jul.-dez., 1985.

CODO, Wanderley (Org.). Educação: carinho e trabalho. Petrópolis: Vozes/CNTE/UnB, 1999.

CORRÊA, Maria L.; TEIXEIRA, Alessandra L. Uma nova faceta da gestão empresarial: a conformação da subjetividade do trabalhador. Trabalho apresentado na $23^{\mathrm{a}}$ Reunião Anual da Anped. In: Anped 25 anos. CDROM histórico, 2002. 
CORRÊA, Vera. Formação da consciência política dos professores em tempos de globalização e neoliberalismo. Trabalho \& Crítica, n. 2, p. 147-160, 2000.

DEJOURS, Christhophe. A loucura do trabalho. Estudo da psicopatologia do trabalho. 5. ed. São Paulo: Cortez/Oboré, 1992.

DELGADO, Darlan M. Inovação, tecnologia e desenvolvimento econômico: a universidade como lócus privilegiado das demandas empresariais. Trabalho apresentado na $29^{\mathrm{a}} \mathrm{Reu}-$ nião Anual da Anped. CD-ROM, 2006.

DELUIZ, Neise. Projetos em disputa: empresários, trabalhadores e formação profissional. Trabalho apresentado na $19^{a}$ Reunião Anual da Anped. In: Anped 25 anos. CD-ROM histórico, 2002.

DUARTE, Luiz Fernando D. Da vida nervosa nas classes trabalhadoras urbanas. Rio de Janeiro, Brasília: Jorge Zahar, CNPq, 1986.

FERREIRA, Maria Onete L. A crise dos referenciais e os pesquisadores em trabalho e educação: o lugar do marxismo entre os educadores. Trabalho apresentado na $24^{\mathrm{a}}$ Reunião Anual da Anped. In: Anped 25 anos. CDROM histórico, 2002.

FERREIRA, Norma S. A. As pesquisas denominadas 'estado da arte'. Educação e Sociedade, n. 79, p. 257-274, ago. 2002.

FIDALGO, Fernando. A formação profissional negociada: França e Brasil, anos 90. Trabalho \& Crítica, n. 1, p. 58-70, 1999.

FRANZOI, Naira L. Da profissão como profissão de fé ao 'mercado em constante mutação': trajetórias e profissionalização dos alunos do plano estadual de qualificação do Rio Grande do Sul (PEQ-RS). Trabalho apresentado na $27^{\mathrm{a}}$ Reunião Anual da Anped. CD-ROM, 2004.

FRIGOTTO, Gaudêncio. Educação, crise do trabalho assalariado e desenvolvimento: teorias em conflito. In: (Org.). Educação e crise do trabalho: perspectivas de final de século. Petrópolis: Vozes, 1998.
A nova e a velha faces da crise do capital e o labirinto dos referenciais teóricos. In: __ _ CIAVATTA, Maria (Orgs.). Teoria e educação no labirinto do capital. Petrópolis: Vozes, 2001.

FRIGOTTO, Gaudêncio; CIAVATTA, Maria; RAMOS, Marise. A gênese do Decreto $\mathrm{n}^{\circ}$ 5.54/2004: um debate no contexto controverso da democracia restrita. In: . (Orgs.).

Ensino médio integrado. Concepção e contradições. São Paulo: Cortez, 2005.

FURTADO, Celso. O capitalismo global. 2. ed. São Paulo: Paz e Terra, 1998.

GENTILI, Pablo. La maldición divina? Las complejas relaciones entre los hombres de negocios y las políticas educativas. Trabalho apresentado na $19^{a}$ Reunião Anual da Anped. In: Anped 25 anos. CD-ROM histórico, 2002a.

Educar para o desemprego: a desintegração da promessa integradora. Trabalho apresentado na $20^{\mathrm{a}}$ Reunião Anual da Anped. In: Anped 25 anos. CD-ROM histórico, 2002b.

Educar para o desemprego: a desintegração da promessa integradora. In: FRIGOTTO, Gaudêncio (Org.). Educação e crise do trabalho: perspectivas de final de século. Petrópolis: Vozes, 1998.

GOMEZ, Carlos Minayo et al. Trabalho e conhecimento: dilemas na educação do trabalhador. São Paulo: Cortez \& Autores Associados, 1987.

GONZALEZ, Wânia Regina C.; MATIAS, José Luiz. ONGs e educação profissional: uma análise crítica das diretrizes pedagógicas pautadas na resolução n. ${ }^{\circ} 194$ de 23 set. 1998 do Codefat. Trabalho apresentado na $27^{\mathrm{a}}$ Reunião Anual da Anped. CD-ROM, 2004.

HOPSTEIN, Graciela. Políticas de 'capacitación' de los trabajadores públicos en el marco de la reforma del Estado en Argentina (1991-1995): formación profesional o búsqueda de consenso? Trabalho \& Crítica, n. 1, p. 43-57, 1999. 
INVERNIZZI, Noela. Qualificação e novas formas de controle da força de trabalho no processo de reestruturação da indústria brasileira; tendências dos últimos vinte anos. In: REUNIÃO ANUAL DA ANPED - Educação não é privilégio (Centenário de Anísio Teixeira), 23, 2000, Caxambu. Programa e resumos.

KUENZER, Acácia Zeneida. Educação e trabalho no Brasil; o estado da questão. Brasília: Inep/MEC, 1987.

Desafios teórico-metodológicos da relação trabalho-educação e o papel social da escola. In: FRIGOTTO, Gaudêncio (Org.). Educação e crise do trabalho: perspectivas de final de século. Petrópolis: Vozes, 1998.

LAUDARES, João Bosco; TOMAS, Antônio. O técnico de escolaridade média no setor produtivo: seu novo lugar e suas competências. Trabalho \& Crítica, n. 3, p. 255-269, 2002.

LEHER, Roberto. Educação e tempo desiguais: reconstrução da problemática trabalho e educação. In: REUNIÃO ANUAL DA ANPED A política de educação no Brasil: globalização e exclusão social, 19, 1996, Caxambu. Programa.

Para fazer frente ao 'apartheid' educacional imposto pelo Banco Mundial: notas para uma leitura da temática trabalho-educação. Trabalho \& Crítica, n. 1, p. 16-29, 1999.

MACÁRIO, Epitácio. Determinações ontológicas da educação: uma leitura à luz da categoria trabalho. In: REUNIÃO ANUAL DA ANPED - Intelectuais, conhecimento e espaço público, 24, 2001, Caxambu. Programa e resumos.

MARKERT, Werner. Trabalho em grupo nas empresas alemãs: um novo modelo de produção e uma proposta conceitual de formação profissional. Trabalho apresentado na $22^{\mathrm{a}}$ Reunião Anual da Anped. In: Anped 25 anos. CD-ROM histórico, 2002a.

Novas competências no mundo do trabalho e suas contribuições para a formação do trabalhador. Trabalho apresentado na $23^{\mathrm{a}}$ Reunião Anual da Anped. In: Anped 25 anos. CD-ROM histórico, 2002b.
Trabalho, universidade, comunicação e sensibilidade - aspectos teóricometodológicos para um conselho dialético de competência. Trabalho apresentado na $24^{\mathrm{a}}$ Reunião Anual da Anped. In: Anped 25 anos. CD-ROM histórico, 2002c.

Trabalho e consciência - mudanças na sociedade do trabalho e a reconstrução da teoria de classe. Trabalho apresentado na $25^{\mathrm{a}}$ Reunião Anual da Anped. CD-ROM, 2002d.

MARTINS, Herbert Gomes. A qualidade total como confirmação do campo pedagógico através da aprendizagem organizada: o caso da Companhia Cervejaria Brahma-RJ. In: REUNIÃO ANUAL DA ANPED - Educação, crise e mudança: tensões entre a pesquisa e a política, 20, 1997, Caxambu. Programa e resumos.

MARX, Karl; ENGELS, Friedrich. A ideologia alemã (Feuerbach). São Paulo: Ciências Humanas, 1979.

MORAES, Carmen Sylvia V. de; FRANCO, Maria Ciavatta. Trabalho e Educação na sociedade brasileira: uma perspectiva histórica. Minicurso. In: REUNIÃO ANUAL DA ANPED Educação, crise e mudança: tensões entre a pesquisa e a política, 22, 1999, Caxambu. Programa e resumos.

NOGUEIRA, Paulo H. Habermas e a não centralidade formativa do trabalho, uma crítica filosófica ao marxismo. In: REUNIÃO ANUAL DA ANPED - Intelectuais, conhecimento e espaço público, 24, 2001, Caxambu. Programa e resumos.

NOSELLA, Paolo; BUFFA, Esther. Escolástica ou historicismo? In: Anped 25 anos. CD-ROM histórico, 2002.

.; __ Artes liberais e mecânicas: a difícil integração. In: REUNIÃO ANUAL DA ANPED - Educação, crise e mudança: tensões entre a pesquisa e a política, 20, 1997, Caxambu. Programa e resumos.

OLIVEIRA, Elenice Gomes de. A reforma e a contra-reforma da educação profissional brasileira. Trabalho apresentado na $27^{\mathrm{a}}$ Reunião Anual da Anped. CD-ROM, 2004. 
OLIVEIRA, Ramon. Possibilidades do Ensino Médio integrado diante do financiamento público da educação. Trabalho apresentado na 30ª Reunião Anual da Anped. CD-ROM, 2007.

OSÓRIO, Antônio Carlos do N.; LEÃO, Inara B. As politicas de educação profissional: discursos e desafios constantes. Trabalho apresentado na $27^{\text {a }}$ Reunião Anual da Anped. CDROM, 2004.

OSOWSKI, Cecília; MARTINI, Jussara Gue. Trabalhadores infanto-juvenis de escolas de primeiro grau; contribuindo para repensar o currículo. Anped, GT Trabalho e Educação. In: Anped 25 anos. CD-ROM histórico, 2002.

PALANGANA, Isilda C. Individualidade: afirmação e negação na sociedade capitalista. In: REUNIÃO ANUAL DA ANPED - Conhecimento e poder: em defesa da universidade pública, 21, 1998, Caxambu. Programa e resumos.

PORTELA, Josania L. Relação: educação, trabalho e cidadania. In: REUNIÃO ANUAL DA ANPED - Educação não é privilégio (Centenário de Anísio Teixeira), 23, 2000, Caxambu. Programa e resumos.

RAMOS, Marise N. Reforma da educação profissional: uma síntese contraditória da (a)diversidade estrutural. Trabalho apresentado na $19^{\text {a }}$ Reunião Anual da Anped. In: Anped 25 anos. CD-ROM histórico, 2002.

REBOUÇAS, Antonio José de A. Insalubridade: morte lenta no trabalho. São Paulo: Oboré, 1989.

RESENDE, Anita C. A. Subjetividade e trabalho ou subjetividade não é cognição. Trabalho \& Crítica, n. 1, p. 160-172, 1999.

RODRIGUES, José. Os empresários do ensino e a reforma da educação superior do governo Lula da Silva. Trabalho apresentado na $29^{a}$ Reunião Anual da Anped. CD-ROM, 2006.

. Pensamento pedagógico industrial. Trabalho apresentado na $21^{\text {a }}$ Reunião Anual da Anped. In: Anped 25 anos. CD-ROM histórico, 2002.
Ainda a educação politécnica: o novo decreto da educação profissional e a permanência da dualidade estrutural. Trabalho, Educação e Saúde, v. 3, n. 2, p. 259-282, set. 2005.

RUMMERT, Sonia M. Capital e trabalho: convergências e divergências quanto à educação básica. Trabalho apresentado na $21^{\text {a }}$ Reunião Anual da Anped. In: Anped 25 anos. CD-ROM histórico, 2002.

SANTOS, Ademir Valdir dos. Os papéis da família e da escola na constituição dos sujeitos: implicações na formação dos trabalhadores. Trabalho apresentado na 28 ${ }^{\mathrm{a}}$ Reunião Anual da Anped. CD-ROM, 2005.

SANTOS, Aparecida de Fátima T. dos. O novo Ensino Médio agora é para a vida: neoliberalismo, racionalidade instrumental e a relação trabalhoeducação na reforma do ensino secundário. Trabalho \& Crítica, n. 3, p. 217-233, 2002.

SANTOS, Eloisa Helena. O saber em trabalho: a experiência de desenvolvimento tecnológico pelos trabalhadores de uma indústria brasileira. Trabalho apresentado na $19^{\text {a }}$ Reunião Anual da Anped. In: Anped 25 anos. CD-ROM histórico, 2002.

SAVIANI, Dermeval. Sobre a concepção de politecnia. Rio de Janeiro: Fiocruz, 1987.

SHIROMA, Eneida; CAMPOS, Roselane F. Qualificação e reestruturação produtiva: um balanço das pesquisas em educação. Educação e Sociedade, n. 61, p. 13-35, dez. 1997.

SILVA, Maria Vieira. O 'ethos' empresarial na educação escolar: novos dispositivos, novas subjetividades. Trabalho \& Crítica, n. 3, p. 183-199, 2002.

SILVA, Tomaz Tadeu da (Org.). Trabalho, educação e prática social: por uma teoria da formação humana. Porto Alegre: Artes Médicas, 1991.

SOARES, Kátia Cristina D. Trabalho e formação docente: tendências no plano das políticas e da literatura especializada. Trabalho apresentado na 29a Reunião Anual da Anped. CDROM, 2006. 
SOARES, Suely Galli. Qualificação: o mito da integração social. Políticas públicas e educação profissional no Estado de São Paulo: aspectos inovadores e pontos críticos. Trabalho \& Crítica, n. 1, p. 71-83, 1999.

SOUZA, Donaldo B. de; SANTANA, Marco Aurélio; DELUIZ, Neise. O entendimento da CUT, CGT e FS sobre o papel da educação face às transformações no mundo do trabalho: tensões e dinâmicas estruturais e conjunturais. Trabalho apresentado na $22^{\mathrm{a}}$ Reunião Anual da Anped. In: Anped 25 anos. CDROM histórico, 2002.

SOUZA, Maria das Graças G. A complementação de escolaridade do trabalhador na empresa: uma experiência baiana. Trabalho apresentado na $20^{a}$ Reunião Anual da Anped. In: Anped 25 anos. CD-ROM histórico, 2002.

SUHR, Inge Renate Fröse. Reforma do Ensino Médio: o discurso da adequação às necessidades da produção e à naturalização da exclusão. Trabalho apresentado na $28^{\text {a }}$ Reunião Anual da Anped. CD-ROM, 2005.

TASSIGNY, Mônica Mota. Trabalho e educação: dimensão ética e perspectiva ontológica. Trabalho apresentado na $28^{\mathrm{a}}$ Reunião Anual da Anped. CD-ROM, 2005.

TOMAS, Antônio; LAUDARES, João Bosco. O técnico de escolaridade média no setor produtivo: seu novo lugar e suas competências. Trabalho \& Crítica, n. 3, p. 255-270, 2002.

TREIN, Eunice; CIAVATTA, Maria. O teórico e empírico do GT Trabalho e Educação: uma análise para debate. Revista Brasileira de Educação, n. 24, p. 140-164, set./out./nov./ dez. 2003.

Pensar o trabalho e a formação integrada. In: CONFERENCIA DE CIENCIAS SOCIALES DE LATINOAMÉRICA Y EL CARIBE/CLACSO - GT Pensamiento Histórico-crítico en América Latina, 6, 2006, Rio de Janeiro. Mimeografado.

TREIN, Eunice. Entrevista. Revista do Nete, n. 0, p. 32-40, jul.-dez. 1996a.
Trabalho e educação diante dos limites da globalização: questões teórico-metodológicas. Revista do Nete, n. 3, p. 119-128, jan.-jul. 1998.

TREIN, Eunice; PICANÇO, Iracy S. O GT Trabalho e Educação. In: Histórico dos grupos de trabalho. Belo Horizonte: Anped, 1995.

TROJAN, Rose Meri. Pedagogia das competências e diretrizes curriculares: a estetização das relações entre trabalho e educação. Trabalho apresentado na 28 ${ }^{\mathrm{a}}$ Reunião Anual da Anped. CD-ROM, 2005.

TRÓPIA, Patrícia Vieira. A inserção dos assalariados não-manuais: um debate com a bibliografia marxista sobre a classe média. Trabalho apresentado na $30^{\mathrm{a}}$ Reunião Anual da Anped. CD-ROM, 2007.

TUMOLO, Paulo Sérgio. O novo padrão de acumulação do capital e a formação sindical da Central Única dos Trabalhadores. Trabalho apresentado na $20^{\mathrm{a}}$ Reunião Anual da Anped. In: Anped 25 anos. CD-ROM histórico, 2002.

A educação frente às metamorfoses do mundo do trabalho: uma proposta de método de análise. Trabalho apresentado na $19^{a}$ Reunião Anual da Anped. In: Anped 25 anos. CD-ROM histórico, 2002.

Reestruturação produtiva no Brasil; um balanço crítico da produção bibliográfica. Trabalho apresentado na $21^{\text {a }}$ Reunião Anual da Anped. In: Anped 25 anos. CDROM histórico, 2002.

Da subsunção formal do trabalho à subsunção real da vida social ao capital: apontamentos de interpretação do capitalismo contemporâneo. Trabalho \& Crítica, n. 2, p. 15-30, 2000.

VENDRAMINI, Célia Regina. Assentamentos do MST e identidade coletiva. Trabalho apresentado na 26a Reunião Anual da Anped. CDROM, 2003.

WILLIAMS, Raymond. Palavras-chave. São Paulo: Boitempo, 2007. 
WITTMANN, Lauro C.; GRACINDO, Regina V. (Coords.). O estado da arte em politica e gestão da educação no Brasil, 1991-1997. Campinas: Anpae/Autores Associados, 2001.
ZIBAS, Dagmar. O reverso da medalha; os limites da administração industrial participativa (um estudo de caso). Trabalho apresentado na $19^{a}$ Reunião Anual da Anped. In: Anped 25 anos. CD-ROM histórico, 2002. 